\title{
A CLUSTER ANALYSIS OF FDI IN LATIN AMERICA
}

\author{
ROsA Forte* \\ NANCY SANTOS ${ }^{* *}$
}

\begin{abstract}
This study contributes to the literature on FDI in Latin America using cluster analysis, a technique rarely employed in studies on this topic, to examine the FDI performance of Latin American countries. The empirical findings reveal three clusters in 2011, compared to just two in 2005. The cluster with better FDI performance (Chile, Panama, Uruguay, and Costa Rica) also performs better in terms of variables such as market size, trade openness, and human capital. Between 2005 and 2011 Argentina left the best-performing cluster and the cluster with poorer performance split into two, indicating heterogeneous evolution of economies in the region.
\end{abstract}

JEL classification: F21, F23, F59

Keywords: Foreign direct investment (FDI), Latin America, cluster analysis

\section{INTRODUCTION}

Over the last 30 years, worldwide foreign direct investment (FDI) flows have experienced strong growth. According to UNCTAD (2010), since 1982 global FDI flows have increased almost 30-fold due to the expansion of multinational enterprise (MNE) activities. ${ }^{1}$ The increase in FDI flows has been sustained by several factors, including the opening of new countries and industries to FDI, greater economic cooperation, privatization, improvements in transport and telecommunications infrastructure, and the increasing availability of financial resources for FDI (UNCTAD, 2010). In 2009, however, due to reduced investment capacity resulting mainly from lower access to credit and weak performance of the world's major economies, FDI inflows decreased globally (UNCTAD, 2010). However, according to the data, in 2011 FDI flows recovered to levels similar to the pre-crisis period (UNCTAD, 2012).

\footnotetext{
* Faculty of Economics and Management, University of Porto, and Center for Economics and Finance at University of Porto (CEF.UP). This research has been financed by Portuguese Public Funds through Fundação para a Ciência e a Tecnologia (FCT) in the framework of the project PEst-OE/EGE/UI4105/2014. Address: Rua Dr. Roberto Frias, 4200 - 464 Porto. Telephone: 00351225571100. Email: rforte@fep.up.pt.

** Faculty of Economics and Management, University of Porto. Email: nancy_santos@hotmail.com. 1. FDI is defined as an investment by an economic entity in a country other than its country of origin. It involves a long-term relationship reflecting an investor's lasting interest in a foreign entity (UNCTAD, 2010).
} 
The drop in FDI registered in 2009 did not affect all countries in the same way. In developed countries, particularly in North America and Europe, there was a reduction of these flows, while in developing countries, particularly in Latin America and Asia, there was growth (UNCTAD, 2010). This discrepancy has accentuated a trend in which developing economies have increased their importance as FDI recipients. In 1990, FDI inflows to Latin America accounted for $4 \%$ of the worldwide total; by 2011 this figure had reached 10\%. Individually, however, countries have shown varying performance. According to data from the UNCTAD (2012) report on Latin America, in 2011 Brazil was the largest recipient of FDI in the region, followed by Mexico, Chile, Colombia, and Peru.

In this context, the aim of this study is to analyze the regional distribution of FDI flows in Latin America using cluster analysis to determine if there are homogeneous groups in the data. Therefore, it is important to ascertain the performance of each country and examine why countries differ in terms of attracting FDI. Our focus on this region is due to the fact that there are few studies about FDI in Latin America.

Although the body of literature on FDI is relatively large, we found that the number of articles focusing on Latin American countries is scarce. Some exceptions are Tuman and Emmert (1999), Treviño and Mixon (2004), Santana and Vieira (2005), Amal and Seabra (2007), Biglaiser and Saats (2010), Bucheli and Aguilera (2010), and Ramirez (2010), which address the determinants of FDI attraction to Latin America. This literature dates to prior to the 2008 crisis or uses data from before 2008; therefore, this study using more recent data may provide new evidence.

A country's ability to attract FDI is influenced by several factors closely related to its location advantages. Among these, according to Dunning and Lundan (2008), are the country's natural resources endowment, the quality and price of inputs, the existence of good infrastructure, market size, lack of trade barriers, an adequate legal and regulatory system, investment incentives, and institutional conditions favorable to multinational enterprises. Therefore, we conduct a review of the literature on the factors that explain the direction of FDI flows and complement this review with a cluster analysis to determine how FDI is distributed in Latin America. The countries under study are then divided into categories based on a set of variables directly related to the 
determinants of FDI attraction, to find out if there are homogeneous groups in the data and classify countries according to their degree of attractiveness. Since there is little empirical evidence on the reasons why multinationals invest in Latin America, this study aims to contribute to knowledge about the determinants of FDI in this region.

The paper is organized as follows: In Section 2 we present a brief review of the literature on the leading location determinants of FDI. In Section 3 we present the methodology and a brief descriptive analysis of the variables (and their proxies) used in the empirical analysis. In Section 4 we present the empirical results obtained from the cluster analysis. Finally, Section 5 contains the main conclusions, limitations, and suggestions for future research.

\section{The LOCATION OF FDI: A Literature REVIEW}

\subsection{Theoretical arguments}

The attractiveness of a country for FDI is strictly related to its location advantages, such as natural resource endowments, the prices and quality of inputs (e.g., labor, energy), infrastructure quality (particularly in terms of transport and communication), market size, lack of trade barriers (e.g., import tariffs), the legal and regulatory system (e.g., protection of property rights), investment incentives, and institutional conditions favorable to MNEs (Dunning and Lundan, 2008). Location advantages are one of three types of advantages reported by Dunning (1980) in his eclectic paradigm as being essential for firms when deciding where to engage in FDI. The other two types of advantages are ownership and internalization. Ownership advantages are directly related to the tangible and intangible assets (e.g., technological and financial capacity, organizational skills, corporate culture) that give MNEs an advantage over their competitors, allowing them to benefit from the location advantages offered by host countries (Dunning, 2001). Internalization advantages reflect the preference of MNEs to internalize (engage in FDI) where the benefits of performing internal operations are greater than employing a market solution (e.g., licensing to external entities) (Dunning, 2001).

Along the same lines, Brewer (1993) argues that factors such as market size and growth, labor availability and costs, inflation, external debt, and the balance of payments situation have always been considered the main indicators of the degree of attractiveness of a location for 
investment projects and international trade. All of these factors reflect a country's macroeconomic conditions. Also, Nonnenberg and Mendonça (2005) consider that the competitive advantage of a particular location has been evaluated in terms of macroeconomic conditions in the existing literature. Table 1 summarizes the main FDI location determinants frequently referred to in the literature and their expected relationship with FDI. ${ }^{2}$

\section{Table 1. FDI location determinants}

\begin{tabular}{lc}
\hline FDI determinant & $\begin{array}{c}\text { Expected relationship } \\
\text { with FDI }\end{array}$ \\
Market size & + \\
Market growth & + \\
Level of trade openness & + \\
Human capital & - \\
Production costs & + \\
Infrastructure & + \\
Financial and fiscal incentives & $-/$ \\
Economic stability & + \\
Corruption, political instability and institutional quality & + \\
Resource endowments & + \\
\hline Source: Authors. & + \\
\hline
\end{tabular}

\section{Market size}

According to Bengoa and Sanchez-Robles (2003), the sunk cost of FDI leads multinational firms to invest in countries with larger market size in order to exploit economies of scale. In this way, countries with large markets reflect higher potential demand (Marr, 1997) and should attract more FDI inflows than smaller countries. Therefore, a positive relationship is expected between market size and FDI flows (Jensen, 2003; Janicki and Wunnava, 2004; Mohamed and Sidiropoulos, 2010; and Choong and Lam, 2010).

2. Note that according to Dunning and Lundan (2008) the relative importance of a location-specific determinant depends on the motive underlying multinationals' investment: access to internal and export markets (market-seeking FDI), access to natural resources and low-cost labor (natural resource-seeking FDI), taking advantage of differences in the availability and relative cost of production factors in different countries (efficiency-seeking FDI), and acquiring the assets of foreign firms in order to promote their own global competitiveness (strategic asset-seeking FDI). 


\section{Market growth}

Regarding market growth, a market with a higher growth rate is expected to receive higher FDI flows (Mohamed and Sidiropoulos, 2010). Multinational firms tend to invest in countries with higher growth performance insofar as they indicate a larger market potential for their products (Marr, 1997).

\section{Level of trade openness}

According to Beven and Estrin (2004), FDI is encouraged if the host country has a liberal trade regime because multinational firms have a higher propensity to export. As Beven and Estrin (2004, p. 779) report, "Third-party countries may invest in host economies within customs unions to avoid tariffs on exports." Hence, a positive relationship between trade openness and FDI is expected.

\section{Human capital}

Concerning human capital, it has been argued in several studies (Brewer, 1993; Jensen, 2003; Nonnenberg and Mendonça, 2005; Choong and Lam, 2010) that a high level of human capital (or skilled labor) is an important and decisive determinant of FDI because education improves the productivity of the labor force and the propensity for technology use and innovation. Therefore, FDI and the level of human capital should be positively related.

\section{Production costs}

Another factor which is usually considered influential in terms of an MNE's decision to engage in FDI is production costs, particularly labor costs. MNEs seek locations where labor costs are lower to increase their competitiveness at the international and local levels (Bevan and Estrin, 2004). Since lower labor costs (measured by wages per worker) generate lower production costs, it is expected that countries with lower labor costs attract/receive more FDI (Dunning and Lundan, 2008). 


\section{Infrastructure}

According to Vijayakumar et al. (2010) and Mohamed and Sidiropoulos (2010), the presence of good infrastructure in a country attracts FDI flows. Poor infrastructure leads to higher transport costs and hampers the movement of goods, thereby affecting firms' location decisions (Mlambo, 2005). It is expected, therefore, that quality of infrastructure and FDI are positively related.

\section{Financial and fiscal incentives}

With regard to tax incentives, liberalization of taxes (tax reductions, subsidies and exemptions) in a host country is widely believed to create incentives for MNEs, since this translates into lower initial costs. In this way, a positive relationship with FDI is expected (Root and Ahmed, 1978).

\section{Economic stability}

According to Cleeve (2008), a country with a stable economy (characterized by price stability, full employment and an adjusted balance of payments) will tend to attract more FDI flows. Macroeconomic uncertainty or instability leads to a higher perception of risk, negatively affecting both domestic and foreign investment (Mlambo, 2005).

\section{Corruption, political instability, and institutional quality}

According to Biglaiser and Staats (2010), political corruption tends to increase the cost of establishing a new plant and creates uncertainty about future payments required by the government. Thus, the existence of corruption will tend to reduce FDI inflows.

Regarding political stability, according to Pastor and Hilt (1993) the type of political system and considerations of economic and political risk may also influence FDI. The authors state that international investors are not attracted by authoritarian regimes. A democratic regime is viewed as providing greater benefits to investors because property rights are better protected than under an authoritarian regime, and are more likely to inspire investor confidence (Pastor and Hilt, 1993). Similarly, Jensen (2003) states that democratic 
institutions present advantages of credibility with respect to supplementary property rights, which, in turn, tend to reduce political risks for potential investors. In contrast, Oneal (1994) argues that authoritarian regimes have advantages over liberal regimes insofar as they install a stable investment climate for investors. Authoritarian regimes generally do not face electoral constraints and have the ability to repress any opposition, and in that sense they may offer advantages over democracies.

Treviño and Mixon (2004), in turn, emphasize the influence of institutions on the behavior and decision-making of MNEs. Their study highlights a macroeconomic approach and an institutional approach (examining political instability, institutional quality, and tax incentives, among others) to explain MNE investment in Latin America. Quoting DiMaggio and Powell (1991), Treviño and Mixon (2004) argue that managers of MNEs should be especially cognizant of the macroeconomic conditions in the host country as well as institutional conditions, given that MNEs have to respect the host country's institutional environment and understand the impact of macroeconomic policies and institutional reforms instituted there.

\section{Resource endowments}

Finally, regarding resource endowments, according to Dunning and Lundan (2008), MNEs can increase their competitiveness by investing in locations that provide high-quality natural resources at a lower cost than the home country. As a result, we can expect a positive relationship between resource endowments and FDI.

\subsection{Empirical findings}

Several empirical studies have analyzed location advantages in order to test the importance of the FDI location determinants identified previously.

According to Mohamed and Sidiropoulos (2010), a country with a larger market size and higher growth rates would be expected to receive higher FDI flows. Tuman and Emmert (1999), Bengoa and SanchezRobles (2003), Santana and Vieira (2005) and Ramirez (2010), focusing their research on Latin American countries, confirmed the expected relationship: They found a statistically significant positive relationship 
between the size and growth of the market and FDI (market size is usually measured by gross domestic product (GDP), GDP per capita and the number of inhabitants, while growth is represented by the growth rate of real GDP). ${ }^{3}$

Theoretically, a positive relationship between trade openness and FDI is expected. The results of this indicator are not, however, free of ambiguity since among the set of countries characterized by a high degree of trade openness, as measured by the weight of foreign trade (exports and imports) in GDP, we find countries with poor results in terms of FDI (ECLAC, 2009). Santana and Vieira (2005), Benito et al. (2007) and Amal et al. (2010) conclude that FDI is positively correlated with trade liberalization in Latin America. However, Tuman and Emmert (1999) do not obtain the same result in their study, since this factor does not have a significant impact on Japanese FDI directed towards Latin America.

Foreign direct investment and human capital level should be positively related. Bengoa and Sanchez-Robles (2003) and Santana and Vieira (2005) point out that the human capital level shows a positive correlation with FDI in Latin America, especially when evidence of skilled labor is high. Measured using the secondary and primary school enrollment ratio, the effect obtained by Bengoa and Sanchez-Robles (2003) is positive. Additionally, Santana and Vieira (2005) use the enrollment rate in secondary education as a proxy for the human capital level and this variable appears with the expected signal (positive and significant) in determining FDI flows in Latin America.

According to Dunning and Lundan (2008), countries with lower labor costs (and thus lower production costs) are expected to attract more FDI. This effect was confirmed by Vijayakumar et al. (2010). However, other authors (e.g., Biswas, 2002) do not obtain clear results on the role of low labor costs in attracting FDI. None of the studies focusing on Latin America (e.g., Bengoa and Sanchez-Robles, 2003; Santana and

3. It is important to stress that these papers focus on various periods of analysis and include different countries in their respective samples. Tuman and Emmert (1999) use a pooled, cross-sectional, time-series data set (1979 to 1992) to develop a multivariate model that examines the impact of macroeconomic and political variables on Japanese FDI in 12 Latin America countries. Bengoa and Sanchez-Robles (2003) focus on the relationship between economic freedom, FDI and economic growth using panel data analysis for a sample of 18 Latin American countries covering 1970-1999. Santana and Vieira (2005) analyze the determinants for attracting FDI in 17 Latin America countries in the period 1970-2000. Finally, Ramirez (2010) estimates a pooled (fixed-effects) FDI investment function in an effort to identify the main economic and institutional determinants of FDI flows to nine Latin American countries during the 1980-2001 period. 
Vieira, 2005; Amal et al., 2010; Biglaiser and Staats, 2010), include this variable as a determinant of FDI, with the exception of Tuman and Emmert (1999). These authors attempt to explain Japanese FDI in Latin America in the period 1972-1992 and include a variable for the annual exchange rate of the yen against other currencies in the 12 countries analyzed to examine the effects of production costs. However, the results obtained are not statistically significant.

Although quality of infrastructure and FDI should be positively related, the conclusions are not unanimous. Vijayakumar et al. (2010) find a positive and statistically significant relationship while Mohamed and Sidiropoulos (2010) find no statistical evidence for the influence of infrastructure in attracting FDI. Bengoa and Sanchez-Robles (2003) use the physical units of railways variable as a proxy for public investment. This may reflect the level of infrastructure, obtaining a positive correlation between this variable and FDI, but it is not significant.

As stated by Root and Ahmed (1978), a positive relationship between financial and fiscal incentives and FDI is expected. Of the studies analyzed, Cleeve (2008) uses financial and tax incentives as a determinant of FDI, seeking to ascertain to what extent they contribute to attracting FDI to Sub-Saharan Africa. To measure this variable the author uses three proxies: temporary tax exemptions, repatriation of profits, and tax concessions for specific sectors. However, the results are not conclusive, since Cleeve does not find a statistically significant relationship between the three variables and FDI for the sample of countries under study. Focusing on Latin America, Tuman and Emmert (1999) analyze the effects of government adjustment policies (which include reduced corporate tax rates and privatization of state enterprises) and conclude that economic adjustment policies have an important impact on FDI.

According to Mlambo (2005), macroeconomic stability promotes investment. Several indicators are used to assess a country's economic stability, but the inflation rate and exchange rate are the most common (Benito et al., 2007). Thus, high inflation rates and large fluctuations in those rates are a symptom of economic instability and may become an obstacle to FDI (Botrić and Škuflić, 2006). Economic freedom is also used to evaluate economic stability. Studies focusing on economic freedom in Latin American countries provide evidence of a positive effect in terms of attraction of FDI inflows. Using indicators from the Heritage Foundation and the Fraser Institute (both organizations 
evaluate characteristics such as the openness of the economy, government intervention, distortions in the economy and levels of corruption), Bengoa and Sanchez-Robles (2003) and Ramirez (2010) show that the level of economic freedom has a positive and significant effect on attracting FDI inflows. Amal et al. (2010) and Ramirez (2010) use the exchange rate to measure economic stability and conclude that its effect is debatable. A depreciation of the currency of the host country encourages multinationals to acquire assets in the country, leading to an increased flow of FDI to the host country. However, an appreciation of the host country's currency may prompt an increase in the purchasing power of citizens, which may also have a positive impact on FDI aimed at supplying the foreign market (market-seeking FDI). In regard to inflation, Bengoa and Sanchez-Robles (2003), Amal et al. (2010) and Benito et al. (2007) demonstrate that the rate of inflation negatively affects FDI in Latin America.

Harms and Ursprung (2002) test the popular hypothesis that multinational firms prefer to invest in countries where civil and political rights are not respected; their results do not support the hypothesis. On the contrary, they conclude that multinational firms seem to be attracted to countries in which individual freedoms are upheld. According to Biglaiser and Brown (2004), the preference for political stability remains an important factor for investment in Latin American countries. The investment risk related to the protection of property rights has a significant effect on attracting FDI to Latin America, together with the existence of a liberal government in the host country (Benito et al., 2007). The differences in macroeconomic and institutional environments between countries are used by Treviño and Mixon (2004) to explain FDI flows to seven countries in Latin America (Argentina, Brazil, Chile, Colombia, Mexico, Peru, and Venezuela) over the period 1988-1999. The results indicate that the institutional environment dominates the macroeconomic environment as a determinant of FDI in Latin America. Since MNEs (who engage in FDI) must deal with the institutional environment of the host country, they undertake FDI in countries where the institutional distance between the home and host country is minimal. Amal and Seabra (2007), exploring the role of institutional variables as determinants of FDI in Latin America, obtain statistically significant coefficients with the expected sign.

Several empirical studies (Deichmann et al., 2003; Asiedu, 2006; Cheung and Qian, 2009; Ledyaeva, 2009, Mohamed and Sidiropoulos, 2010) 
confirm the expected positive relationship between resource endowment and FDI. None of the studies analyzing Latin America (e.g., Bengoa and Sanchez-Robles, 2003; Santana and Vieira, 2005; Amal et al., 2010; Biglaiser and Staats, 2010) include resource endowment as a determinant of FDI.

In sum, several empirical studies have been performed to identify the main determinants of attraction of FDI to a particular location. However, although these studies have focused on emerging markets (e.g., Brewer, 1993), developing countries (e.g., Root and Ahmed, 1978; Nonnenberg and Mendonca, 2005; Neumayer and Spess, 2005; Mohamed and Sidiropoulos, 2010), European transition economies (Bevan and Estrin, 2004) and BRICS ${ }^{4}$ (Vijayakumar et al. (2010), there have been relatively few studies on Latin America. Those that focus on Latin America identify several determinants of the flow of FDI to this region, including market size and growth, level of trade openness, human capital (education level), tax liberalization, and economic and political stability of the host country (although the latter factor reveals a certain ambiguity about the expected effect). As reported by Porzecanski and Gallagher (2007), there is unanimity among empirical studies on FDI in Latin America that the key determinants of FDI in the region are the (large) size and growth of the market, and a (low) level of inflation and debt (that is, macroeconomic stability). In this paper, our aim is to improve our knowledge about FDI in Latin America using cluster analysis, a technique rarely used in studies on this topic. Cluster analysis allows for grouping countries according to their similarities in terms of a set of variables directly related to FDI location determinants.

\section{MethodologicAl APPROACH}

\subsection{FDI in Latin America}

As stated by the International Monetary Fund (IMF, 1993, p. 86), "Direct investment is the category of international investment that reflects the objective of a resident entity in one economy obtaining a lasting interest in an enterprise resident in another economy. (...) The lasting interest implies the existence of a long-term relationship between the direct investor and the enterprise and a significant degree 
of influence by the investor on the management of the enterprise." Components of FDI include equity capital, reinvested earnings, and other capital associated with inter-company debt transactions.

Foreign direct investment is regarded as the type of capital flow that causes the fewest adverse effects in the host country (ECLAC, 2009). In the case of Latin America, FDI has been an important source of external financing for growth, reducing problems associated with the lack of domestic savings (Santana and Vieira, 2005). This region has also seen an increase in its importance as a recipient of FDI: In 1990 Latin America absorbed 4\% of global FDI, while in 2011 it accounted for 10\% (UNCTAD, 2012). When considered individually, however, the countries in Latin America perform very differently (Figure 1).

\section{Figure 1. FDI inflows to Latin America by host economy}

\section{(\% of total FDI to Latin America, average 2007 - 2011)}

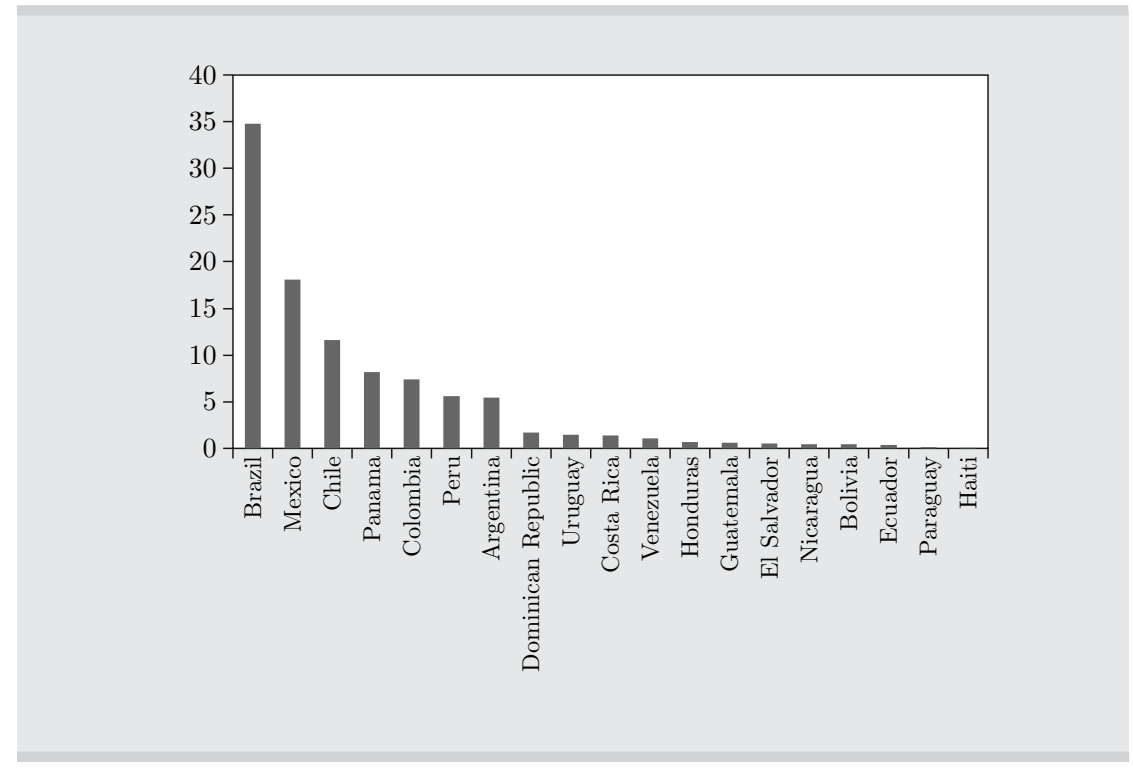

Source: Authors' calculations, based on UNCTAD data.

To measure the performance of countries in this region, we compare each country's share of FDI inflows to total FDI flows to Latin America. We use the average for a five-year period, 2007-2011, to account for variations over the period analyzed since FDI flows can fluctuate significantly from year to year. 
Of the 19 countries in Latin America, we find that Brazil is the largest recipient of FDI, followed by Mexico, Chile, Panama, and Colombia. ${ }^{5}$ At the other end of the spectrum are Haiti, Paraguay, and Ecuador. Although intraregional investment is important-according to UNCTAD (2013a), about half of the investment in Chile in 2011 originated in the Latin American and Caribbean region, namely Brazil and Colombia - the United States is a major investor in the region, as about half of FDI in Mexico in 2011 originated in the U.S. (UNCTAD, 2013b).

A comparison of the share of FDI net inflows to GDP significantly changes the ranking of countries, but there is still a very uneven distribution: Panama is at the top of the list, followed by Nicaragua, Chile, and Honduras, while Ecuador appears at the bottom of the ranking (Figure 2).

Figure 2. FDI, net inflows, 2011

(\% of GDP)

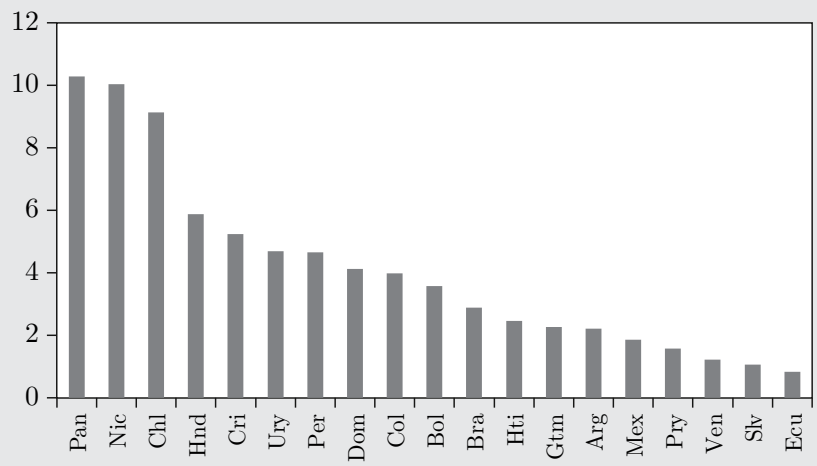

Source: Authors' calculations, based on World Bank data.

It is clear that FDI is not distributed uniformly in the region, as just one country absorbs more than one-third of all FDI flows.

5. Cuba was not included in the study due to the lack of statistical information for most of the selected variables. 
Regarding the variables related to the determinants of attracting FDI identified in Section 2, similar to OECD (2012) we include a set of economic, social, and institutional variables that are indicative of a country's structural characteristics. Given the international dimension of our sample (19 countries in Latin America) we identify the variables associated with each factor, which may prove important in explaining the growth and direction of FDI flows in this region. The variables and their proxies that serve as the basis of this analysis are shown in Table 2, which also provides descriptive statistics of the data.

Since the aim of this study is to analyze the regional distribution of FDI and the characteristics of countries in each cluster in relation to FDI determinants, we use FDI net inflows as a percentage of GDP (because larger markets are expected to attract more FDI). Panama has the highest value at $10.3 \%$ and Ecuador has the lowest one $(0.8 \%)$; the average is $4.1 \%$.

In regard to the remaining variables, starting with GDP per capita (the proxy used for market size, similar to Bengoa and Sanchez-Robles, 2003; Santana and Vieira, 2005; and Ramirez, 2010), we find an average of USD 6,879.80. Chile has the highest value (USD 14,501.20) and Haiti has the lowest value (USD 732.20). To measure market growth, we use the annual growth rate of real GDP as a proxy, following Tuman and Emmert (1999). The average value for the region is 5.5\%, with Panama at the top of the ranking (10.6\%) and El Salvador at the bottom (2.2\%).

As for economic stability, we use the inflation rate as a proxy for this factor. High inflation rates are a classic symptom of a runaway economy in a country, both fiscally and monetarily, so the inflation rate is used to measure the level of economic instability (e.g., Nonnenberg and Mendonça, 2005). The average recorded for this variable is $7 \%$. Venezuela has the highest value $(24.5 \%)$ while Chile and Mexico have the lowest inflation (3\%).

To measure the level of trade openness we use the weight of foreign trade (sum of exports and imports) in GDP, following Janicki and Wunnava (2004) and Benito et al. (2007). The highest value corresponds to Panama (168.2\%) while Brazil has the lowest value (24.5\%), and the average is $72.7 \%$.

To measure the quality of infrastructure we use two proxies: the number of telephone lines per 100 inhabitants and the Logistics Performance Index. Given that this study focus mostly on developing countries, we understand, as did Mohamed and Sidiropoulos (2010), that the first 


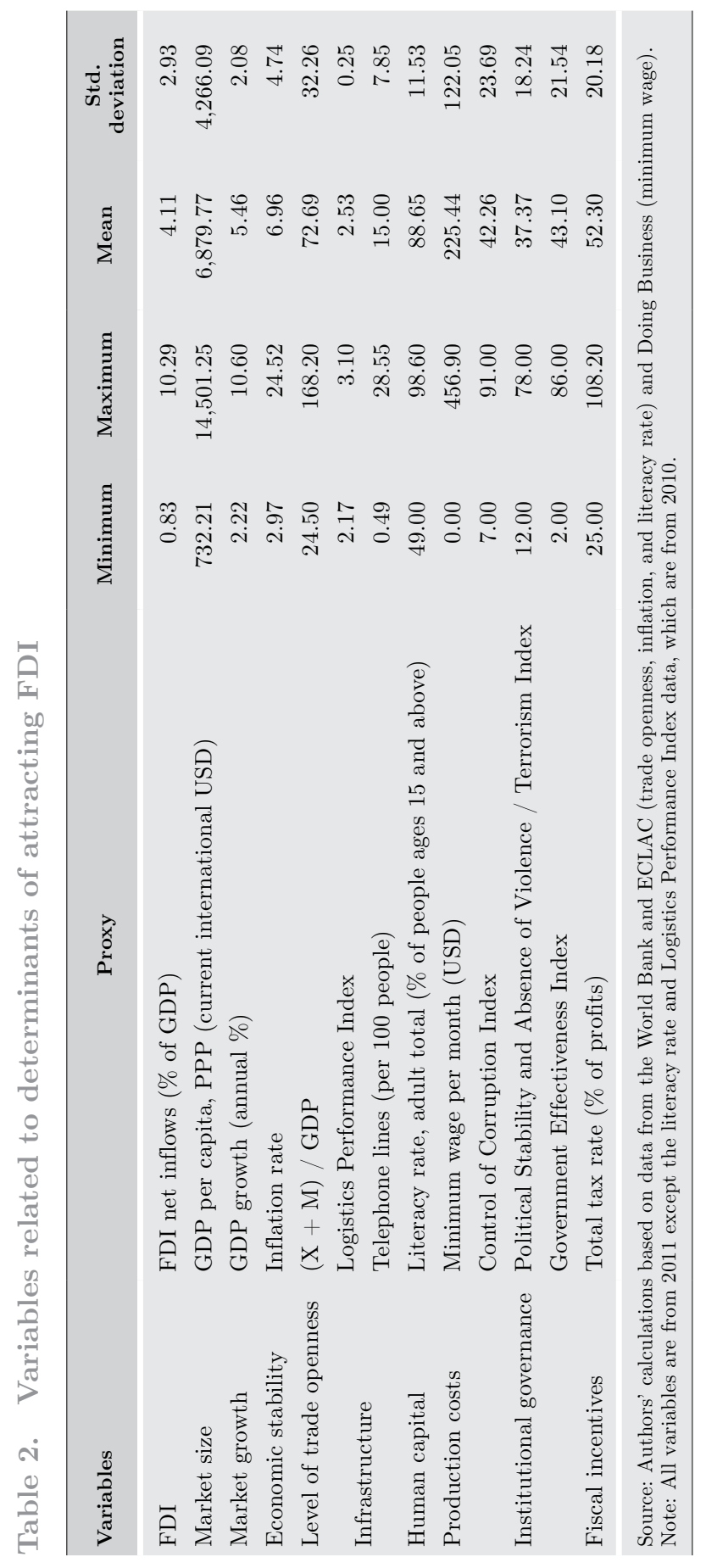


proxy may better reflect the degree of development in this region. The average of this variable is 15 , the highest value (28.5) corresponds to Uruguay and the lowest value $(0.5)$ is obtained by Haiti. The Logistics Performance Index, meanwhile, is intended to measure the quality of trade and transport-related infrastructure, with values ranging from 1 to 5 ( 1 =lowest, $5=$ highest). The average for the region is 2.5 , with the highest value of 3.1 recorded for Brazil and the lowest value of 2.2 recorded for Haiti, Nicaragua, and Bolivia.

To measure the human capital level, we use the total literacy rate of adults (which corresponds to the percentage of people aged 15 years and above who can read and write) since it depicts the accumulated stock of human capital in the region (e.g., Tuman and Emmert, 1999). The literacy rate average is $88.7 \%$. Note that Haiti registers the minimum value of $49 \%$ while Chile has the highest literacy rate $(98.6 \%)$.

Concerning production costs, particularly labor costs, we used the minimum monthly wage (USD) obtained from Doing Business to measure this determinant. For this variable, with an average of USD 225.40, the highest value (USD 456.90) is obtained by Argentina while the minimum value $(0)$ is obtained by Chile.

In terms of institutional governance, we used the three dimensions of governance included in the Worldwide Governance Indicator of the World Bank: the Control of Corruption Index, the Political Stability and Absence of Violence Index, and the Government Effectiveness Index.

The Control of Corruption Index measures "the extent to which public power is exercised for private gain, including both petty and grand forms of corruption, as well as 'capture' of the state by elites and private interests" (Kaufmann et al., 2007, p. 4). The range of this index is 0 to 100. A high (low) index represents low (high) perception of corruption. The average for this variable is 42.3 , where Chile has the highest value at 91 , indicating that it has a low perception of corruption, and Haiti has the lowest value of 7 , evidencing a high perception of corruption.

The Political Stability and Absence of Violence Index measures "perceptions of the likelihood that the government will be destabilized or overthrown by unconstitutional or violent means, including domestic violence and terrorism" (Kaufmann et al., 2007, p. 3) and ranges from 0 (lowest) to 100 (highest). The Government Effectiveness Index reflects "the quality of public services, the quality of the civil service and the degree of its independence from political pressures, the quality of policy formulation and implementation, and the credibility of the 
government's commitment to such policies" (Kaufmann et al., 2007, p. 3) and ranges from 0 (lowest) to 100 (highest). These two indexes were also used by Benito et al. (2007) and Amal et al. (2010) as proxies for political stability in a country. The average for the Political Stability and Absence of Violence Index is 37.4: Uruguay has the highest value at 78, maintaining a stable policy without any conflicts, while Colombia registers the lowest value of 12. Lastly, the Government Effectiveness Index average is 43.1: Chile registers the highest value of 86 and Haiti shows the lowest efficiency in government, with a value of 2 .

To represent tax incentives, including tax reduction, we use the total tax rate, which measures the amount of taxes to be paid by firms after accounting for deductions and exemptions (World Bank, 2004). Regarding the tax rate, with an average of $52.3 \%$, the highest value is $108.2 \%$ in Argentina, while Chile records the lowest value of $25 \%$.

To sum up, the descriptive analysis reveals striking differences between countries concerning the variables reported. Next, using cluster analysis, a multivariate exploratory technique that allows for grouping entities with common characteristics (Maroco, 2007), we intend to gauge whether the 19 Latin American countries contain homogeneous groups and identify the factors that contribute to this homogeneity.

\subsection{Cluster analysis}

Through cluster analysis we can partition entities about which we have detailed information into relatively homogeneous groups or clusters (Johnson and Wichern, 1998 in Yu and Zhang, 2007). In this way, countries (entities) within a cluster are more similar to each other than to countries outside the cluster. Note that according to Maroco (2007), this method is appropriate when there is great variability in the data and for small samples, which is the case in this study: the sample consists of 19 Latin American countries with varying performance in terms of FDI inflows.

Several authors have adopted cluster analysis in different contexts. This technique was used by Duran and Ubeda (2001) in a new approach to the theory of "investment development path (IDP)." The authors conclude that variables related to education, research, development and patents, tariffs and taxes, and health help to better define the level of development. Yu and Zhang (2007) also use cluster analysis to study the regional distribution of FDI in China. Yu and Zhang's (2007) empirical results reveal some insights into the ability 
of Chinese regions to attract FDI. For example, the authors conclude that Guangdong Province has the highest level of FDI, which is consistent with its leading position in hosting FDI and its perceived economic development. $\mathrm{Yu}$ and Zhang (2007) argue that the results of cluster analysis are consistent with reality. Additionally, BoudierBensebaa (2008, p. 38), analyzing "whether or not the differences in the FDI-assisted development paths among the CEECs have become more significant" also resort to cluster analysis in order to form more homogeneous groups of countries. Finally, the OECD (2012), in a study aimed at reviewing the experience of Costa Rica in terms of attracting knowledge-intensive FDI, also uses this technique to position Costa Rica in relation to its regional peers and emerging countries in Asia and the OECD.

As mentioned above, cluster analysis is a procedure of multivariate statistics that attempts to organize a set of entities (individuals or objects), for which detailed information is known in regard to several variables, into relatively homogenous groups (Maroco, 2007). In our study, the set of entities corresponds to 19 Latin American countries. The cluster analysis enables us to classify the countries on the basis of existing information, so that countries belonging to the same group are as similar as possible, and always more similar to the members of the same group than to members of other groups. Regarding the variables, in addition to FDI flows we focus on a set of economic, social, and institutional variables that are presented in Table 2. This analysis enables identification of groups of countries that are more likely to receive FDI and development of hypotheses concerning the structural relationships between variables (Maroco, 2007). Cluster analysis, therefore, shows how countries are positioned in relation to their regional peers, which is not possible using regression methods. ${ }^{6}$

The use of cluster analysis requires the definition of a similarity (or distance) measure between two countries and selection of an aggregation method that defines a split algorithm. For the aggregation, we apply the hierarchical method to form clusters. ${ }^{7}$ Under the hierarchical clustering method each observation (country) is a small cluster at the beginning. 
Subsequently, the distances between clusters are calculated and the two closest clusters are merged to form a new, larger cluster (clusters are merged according to similarity). This procedure is repeated until all observations are merged into a final, large cluster that consists of the entire sample (Liang, 2010). Therefore, it becomes necessary to define a method of grouping the clusters. For the statistical method we use the method of the furthest distance (complete linkage or furthest neighbor). ${ }^{8}$ In this method, the distance between two groups is the maximum distance between pairs of elements, which tends to produce more compact clusters (Brochado, 2005) and minimize the distance between clusters. This method is also one that produced an interpretable solution to the study, as confirmed by the dendrogram (Figure 3). Regarding the measure of similarity (distance), there are several possible measures (see Maroco, 2007 for a review of them). In our study we use the squared Euclidean distance, since it is the measure most frequently used in cluster analysis (Maroco, 2007) ${ }^{9}$ : The smaller the Euclidean distance, the smaller the dissimilarity (or the greater the similarity or proximity) between two countries, and the greater the Euclidean distance, the greater the dissimilarity (or distance) between the countries under analysis (Maroco, 2007). To avoid dependence on measurement units, we follow Kaufman and Rousseeuw's (2005) suggestion and standardize the data.

\section{FDI IN LATIN AMERICA: EMPIRICAL RESULTS}

The present study seeks to analyze the regional distribution of FDI flows in Latin America using a cluster analysis method. This analysis will determine if there are homogeneous groups in the data with respect to the main attractiveness factors identified in the literature as explaining FDI flows to Latin America, such as market size and growth, level of trade openness, quality of infrastructure, human capital, production costs, and economic and political stability. The results are presented in Figure 3.

\footnotetext{
8. There are other connecting methods available for calculating the distance between clusters. We highlight the method of least distance (nearest neighbor) and other methods that tend to have intermediate characteristics between the two most extreme methods (Johnson, 1998 in Maroco, 2007).

9. According to the author (Maroco, 2007, quoting Johnson and Wichern, 2002), for $p$ variables the Euclidean distance between individuals $i$ and $j$ is given by $D_{i j}=\sqrt{\sum_{k=1}^{p}\left(x_{i k}-x_{i j}\right)^{2}}$ where $x i k$ and $x j k$ are the values of variable $k$ in the subjects $i$ and $j$, respectively.
} 


\section{Figure 3. Cluster analysis dendrogram (2011)}

\section{Furthest neighbor method}

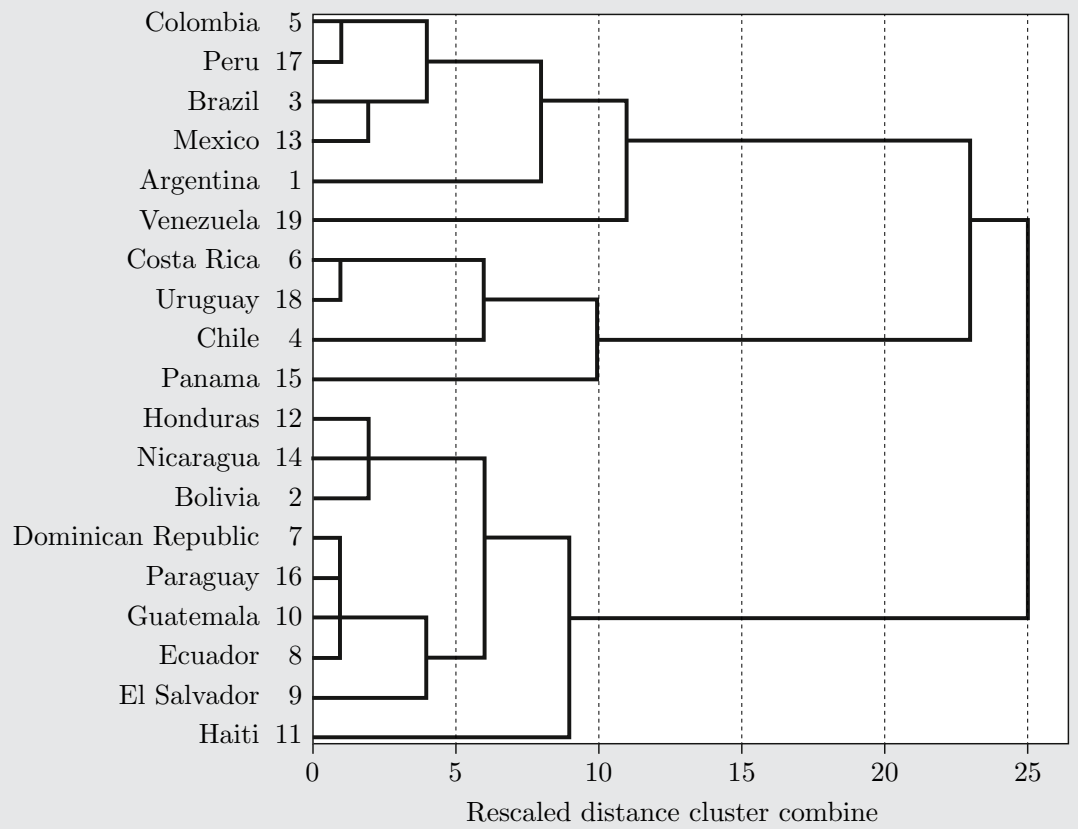

Source: Authors' calculations, using SPSS.

Table 3. Cluster analysis results, 2011

\section{Cluster 1 (6 countries)}

Peru (7)

Colombia (9)

Brazil (11)

Argentina (14)

Mexico (15)

Venezuela (17)

\section{Cluster 2 (9 countries)}

Nicaragua (2)

Honduras (4)

Dominican Republic (8)

Bolivia (10)

Haiti (12)

Guatemala (13)

Paraguay (16)

El Salvador (18)

Ecuador (19)

Source: Authors' calculations.

Cluster 3 (4 countries)

$$
\begin{gathered}
\text { Panama (1) } \\
\text { Chile (3) }
\end{gathered}
$$

Costa Rica (5)

Uruguay (6) 
From the dendrogram we obtain different structures (varying numbers of groups) by cutting the dendrogram at different levels. To obtain the optimum number of groups we use a visual inspection approach, that is, visually identifying classes that are relatively dense and entirely distinguishable from each other, such that more compact clusters are formed (Brochado, 2005). Thus, by making a horizontal cut at a distance of 15 (or 20), we obtain three groups (clusters). Countries within each cluster are shown in Table 3. Each country's ranking in terms of FDI as a percentage of GDP in 2011 is also presented in parentheses.

The group of four countries included in cluster 3 (see Table 3) suggests that this cluster has better performance in terms of FDI, since all the countries included present a value above average for FDI as a percentage of GDP variable. We then examine the three clusters by comparing the averages of several variables using the Kruskal-Wallis nonparametric test in order to verify if the differences are statistically significant (see Table 4).

According to Table 4, in terms of FDI (percentage of GDP), cluster 3 has a higher average than the other two clusters and the differences are statistically significant. Thus, the countries in cluster 3 may be regarded as the most attractive for FDI.

Concerning the variables usually identified in the literature as affecting FDI flows, we find that there are statistically significant differences between the three clusters in regard to several variables, namely GDP per capita, level of trade openness, the Logistics Performance Index, the number of telephone lines per 100 inhabitants, the literacy rate, the Control of Corruption Index, the Political Stability and Absence of Violence/Terrorism Index, and the Government Effectiveness Index. These variables, particularly GDP per capita, reflect a country's level of economic development (Thorn, 1968). Thus, the cluster analysis performed allows us to separate the 19 Latin American countries into three groups that each represent a quite distinct level of economic development. There are no statistically significant differences regarding the variables of GDP growth, inflation rate, minimum wage, and total tax rate.

Table 4 shows that cluster 3, which performs better in terms of FDI, also exhibits better performance in almost all of the variables, namely GDP per capita, level of trade openness, number of telephone lines per 100 inhabitants, literacy rate, and the three indexes related to institutional governance. This is in line with what we would expect according to FDI location determinants. 


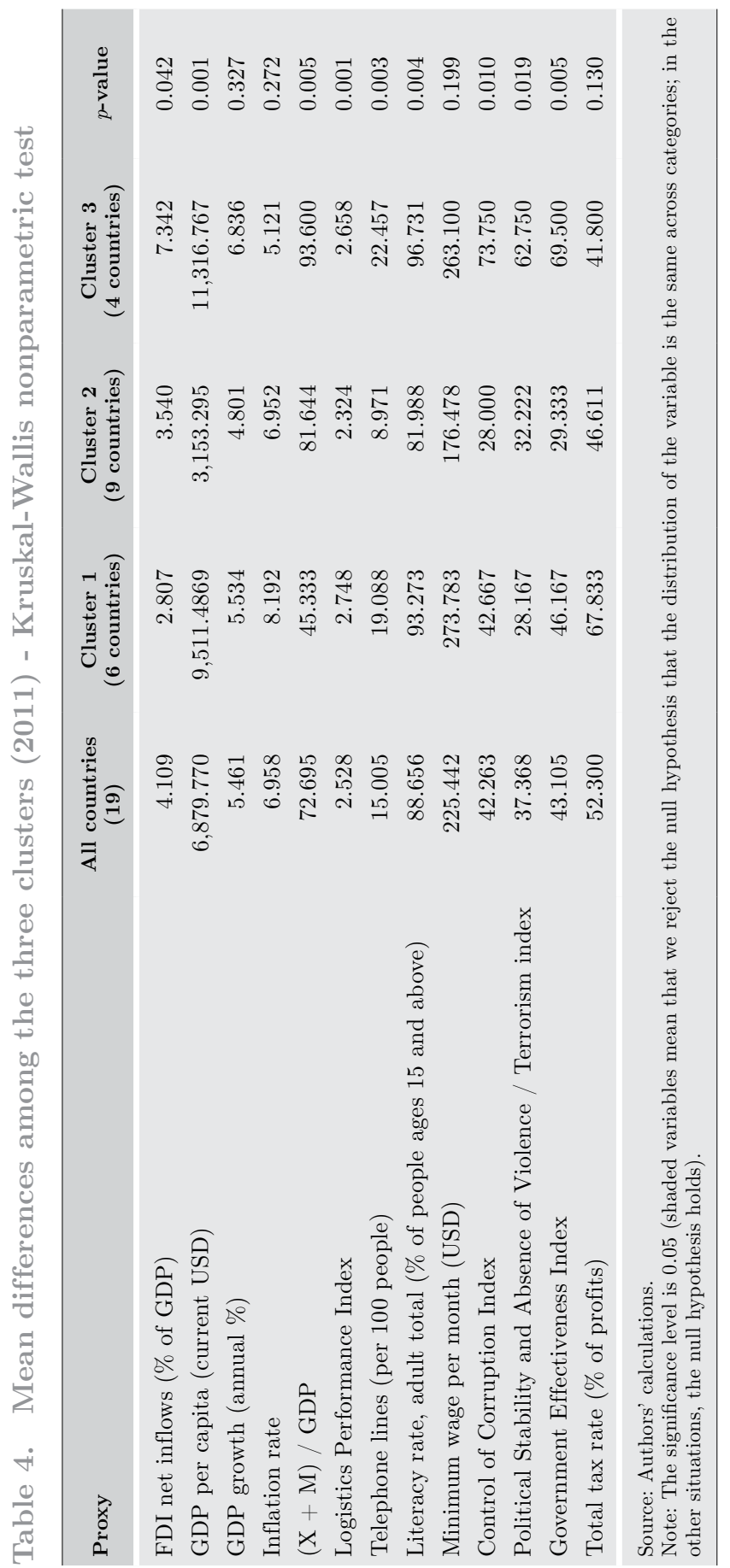


Regarding the other two clusters (cluster 1 with six countries and cluster 2 with nine countries), both have an average FDI variable below the overall average (all countries), although cluster 2 has performed better. In terms of the remaining variables, cluster 2 also has better indicators for level of trade openness and political stability, suggesting that countries with higher scores in these variables also have better performance in terms of FDI.

In summary, we find that cluster 3, consisting of four countries (Chile, Panama, Uruguay, and Costa Rica), performs better in terms of a set of FDI determinants such as market size, level of trade openness, quality of infrastructure, human capital, and institutional governance.

In order to compare the evolution of country homogeneity profiles we perform a similar analysis for an earlier year (2005). From the dendrogram (Figure A1 in the Appendix), making a horizontal cut at a distance of 15 (or 20) we obtain two groups (clusters). The countries in each cluster are shown in Table 5. The results of the Kruskal-Wallis nonparametric test are presented in Table A1 in the Appendix.

Table 5. Cluster analysis results, 2005

\begin{tabular}{lcc}
\hline Cluster 1A (5 countries) & \multicolumn{2}{c}{ Cluster 2A (14 countries) } \\
Chile & Brazil & Guatemala \\
Panama & Mexico & El Salvador \\
Uruguay & Colombia & Nicaragua \\
Costa Rica & Peru & Bolivia \\
Argentina & Dominican Republic & Ecuador \\
& Venezuela & Paraguay \\
& Honduras & Haiti \\
\hline Source: Authors' calculations. & & \\
\hline
\end{tabular}

The group of five countries in cluster 1A (see Table 5) suggests that it has higher performance in terms of FDI, since almost all the countries (except Argentina) present an above average value for the FDI as a percentage of GDP variable. Cluster $1 \mathrm{~A}$ also performs better in terms of other variables, namely GDP per capita, the Logistics Performance Index, the number of telephone lines per 100 inhabitants, the literacy rate, the Control of Corruption Index, the Political Stability and Absence of Violence/Terrorism Index, and the Government Effectiveness Index (Table A1 in the Appendix). 
Comparing Table 5 with Table 3, it is evident that between 2005 and 2011 Argentina moved away from the group of countries with the best performance in terms of FDI. Additionally, the other cluster (cluster 2A), which in 2005 comprised 14 countries, split into two clusters: one consisting of six countries and the other with the remaining nine countries (clusters 1 and 2, respectively). This division into two clusters indicates that the group of nine countries (cluster 2) became more attractive for FDI, performing better than the six countries in cluster 1 . Since these two clusters also show statistically significant differences for other variables-in particular cluster 2 has on average better results for the level of trade openness and political stability variables-the growth between 2005 and 2011 seems to indicate that countries that evolve favorably in terms of these variables were able to capture more FDI. These results have important and encouraging policy implications, particularly for countries that have traditionally received smaller amounts of FDI, indicating that it is possible to attract FDI by promoting political stability and opening borders to international trade.

\section{Conclusions}

Increased global FDI flows in recent decades have resulted from the expansion of activities by MNEs abroad. This expansion has been sustained by several factors, including greater openness of more countries and industries to foreign direct investment, increased economic cooperation, privatization, improvements in transport and telecommunications infrastructure, and the growing availability of financial resources for FDI (UNCTAD, 2010). This expansion has largely taken place in developing countries, specifically in Latin America and Asia (UNCTAD, 2010). Although FDI flows fell worldwide in 2009 as a result of reduced access to credit and sluggish economic performance following the crisis (UNCTAD, 2010), not all countries were affected in the same way. In fact, in developed countries, notably in North America and Europe, there was a reduction in these flows while developing countries, particularly in Latin America and Asia, saw an increase (UNCTAD, 2010).

To understand the growth of FDI flows, particularly in Latin America, this study sought to examine the distribution of FDI in the region. Using cluster analysis, the 19 Latin American countries (Cuba was excluded due to missing data) were divided according to a set of 
variables directly related to FDI determinants such as market size (measured by GDP per capita), the quality of infrastructure (measured by the number of telephone lines per 100 inhabitants and a Logistics Performance Index), human capital (measured by literacy rates), and institutional governance (measured by the Control of corruption Index, the Political Stability and Absence of Violence Index, and the Government Effectiveness Index), among others.

According to the results of the cluster analysis, and based on the Kruskal-Wallis nonparametric test, in 2011 there were three clusters that show statistically significant differences in terms of several variables: FDI as a percentage of GDP, GDP per capita, level of trade openness, Logistics Performance Index, number of telephone lines per 100 inhabitants, literacy rate, Control of Corruption Index, Political Stability and Absence of Violence/Terrorism Index, and Government Effectiveness Index. Cluster 3, which consists of four countries (Chile, Panama, Uruguay, and Costa Rica), performs better on these variables that have been identified in the literature as influencing the attraction of FDI (except for the Logistics Performance Index). Additionally, a comparison of the homogeneity profiles between 2005 and 2011 reveals significant differences. In 2005 there were just two clusters, and the one with better performance in terms of FDI is made up of five countries, four of which remain in the cluster with the best FDI performance in 2011 (Argentina was no longer in that group). The fact that between 2005 and 2011 one of the clusters split into two clusters indicates that there were differences in FDI attraction patterns among the region's countries. The cluster analysis shows quite distinct levels of economic development among Latin American countries, suggesting that the group of countries with better performance in terms of certain variables is the one that also has the highest FDI flows.

The cluster of countries with the highest levels of development (Chile, Panama, Uruguay, and Costa Rica) is also the cluster in which FDI is above average; this may indicate, in line with the results obtained by other authors (e.g., Tuman and Emmert, 1999; Bengoa and SanchezRobles, 2003; Santana and Vieira, 2005; Biglaiser and Saats, 2010; Ramirez, 2010) that market size, quality of infrastructure, trade openness, and political stability are important determinants of FDI in Latin America.

It should be noted, however, that this study has some limitations, including gaps in the statistical information regarding most of the 
selected variables; this is particularly true for Cuba, causing its exclusion from the analysis. In future studies on FDI in Latin America it would be interesting to study whether it is possible to prove the importance of the variables examined in this paper as determinants of FDI using multivariate econometric analysis.

In terms of policy implications, the governments of host countries with lower FDI inflows should increase their support for promoting and sustaining investment to generate development and economic growth, defining the best government policy for this purpose along the lines of Pastor and Hilt (1993) and Jensen (2003) concerning the political regime and political stability. Additionally, since the empirical results reveal insights into the ability of countries to attract FDI, they are important to those making decisions about future investment. 


\section{REFERENCES}

Amal, M. and F. Seabra (2007), "Determinantes do IDE na América Latina: Uma perspectiva institucional," Revista Economia 8(2): 231-47.

Amal, M., B. Tomio, and H. Raboch (2010), "Determinants of foreign direct investment in Latin America," Globalization, Competitiveness and Governability, 4(3): 116-133.

Asiedu, E. (2006), "Foreign direct investment in Africa: The role of natural resources, market size, government policy, institutions and political instability," World Economy 29(1): 63-77.

Bengoa, M. and B. Sanchez-Robles (2003), "Foreign direct investment, economic freedom and growth: New evidence from Latina America," European Journal of Political Economy 19(3): 529-45.

Benito, S., A. Cunha, M. Lélis, and J. Bichara (2007), "O IDE espanhol na América Latina: Determinantes e impactos," Cadernos PROLAMIUSP 6(1): 149-86.

Bevan, A. and S. Estrin (2004), "The determinants of FDI into European transition economies," Journal of Comparative Economics 32(2): 775-87.

Biglaiser, G. and D. Brown (2004), "Political stability and foreign direct investment in Latin America," Western Political Science Association 9(2),11-13.

Biglaiser, G. and J. Staats (2010), "Do political institutions affect foreign direct investment? A survey of U.S. corporations in Latin America," Political Research Quarterly 63(3): 508-22.

Biswas, R. (2002), "Determinants of foreign direct investment," Review of Development Economics 6(3): 492-504.

Bloningen, B.A. (2005). "A Review of the Empirical Literature on FDI Determinants". Atlantic Economic Journal. 33 (4), 383-403.

Botrić, V. and L. Škuflić (2006), "Main determinants of foreign direct investment in Southeast European countries," Transition Studies Review, 13(2): 359-77.

Boudier-Bensebaa, F. (2008), "FDI-assisted development in light of the investment development path paradigm: Evidence from Central and Eastern European countries," Transnational Corporations 17(1): 37-67.

Brewer, T.A. (1993), "FDI in emerging market countries," in Oxelheim, L., ed., The global race for FDI: Prospects for the future. Berlin: Springer-Verlag.

Brochado, A. (2005), "A análise de clusters: técnica de classificação na análise espacial," in Costa, J. S., ed., Compêndio de Economia Regional. Associação Portuguesa para o Desenvolvimento Regional: 733-57.

Bucheli, M. and R. Aguilera (2010), "Political survival, energy policies, and multinational corporations," Management International Review 50(3): 347-78.

Cheung, Y-W. and X. Qian (2009), "Empirics of China's outward direct investment," Pacific Economic Review 14(3): 312-41.

Choong, C. and S. Lam (2010), "The determinants of foreign direct investment in Malaysia: A revisit," Global Economic Review 39(2): 175-95. 
Cleeve E. (2008), "How effective are fiscal incentives to attract FDI to Sub-Saharan Africa?" The Journal of Developing Areas 42(1): 135-53.

Deichmann, J.I., A. Eshghi, D.M. Haughton, S. Sayek, and N.C. Teebagy (2003), "Foreign direct investment in the Eurasian transition states," Eastern European Economics 41(1): 5-34.

Dunning, J. (2001), "The eclectic (OLI) paradigm of international production: Past, present and future," The Economics of Business 8(2): 173-90.

Dunning, J. (1980), "Toward an eclectic theory of international production: Some empirical tests," Journal of International Business Studies 11(1): 9-31.

Dunning, J. and S. Lundan (2008), Multinational enterprises and the global economy. Edward Elgar: Cheltenham, U.K.

Duran, J.J. and F. Ubeda (2001), "The investment development path: a new empirical approach and some theoretical issues," Transnational Corporations 10(2): $1-34$.

ECLAC (2009), O investimento estrangeiro directo na América Latina e no Caribe. Relatório 2009. New York: Economic Commission for Latin America and the Caribbean, United Nations.

Harms, P. and H. Ursprung (2002), "Do civil and political repression really boost foreign direct investments?" Economic Inquiry 40(4): 651-64.

International Monetary Fund (1993), Balance of payment manual, 5th edition, Washington, D.C.: IMF Publications.

Janicki, H. and P. Wunnava (2004), "Determinants of foreign direct investment: Empirical evidence from EU accession candidates," Applied Economics 36: $505-9$.

Jensen, N. (2003), "Democratic governance and multinational corporations: Political regimes and inflows of foreign direct investment," International Organization 57(3): 587-616.

Kaufman, L. and P. Rousseeuw (2005), Finding Groups in Data: An Introduction to Cluster Analysis. Hoboken, NJ: John Wiley \& Sons.

Kaufmann, D., A. Kraay, and M. Mastruzzi (2007), "Governance matters VI: Aggregate and individual governance indicators for 1996-2006," World Bank Policy Research Working Paper 4280.

Ledyaeva, S. (2009), "Spatial econometric analysis of foreign direct investment determinants in Russian regions," World Economy 32(4): 643-66.

Liang, H. (2010), "Three essays on the determinants of foreign direct investment" (PhD thesis), The City University of New York.

Maroco, J. (2007), Análise estatistica - Com utilização do SPSS. Lisbon: Edições Sílabo.

Marr, A. (1997), "FDI flows to low income countries: a review of the evidence," Overseas Development Institute Briefing Paper.

Mlambo, K. (2005), "Reviving foreign direct investments in Southern Africa: Constraints and policies," African Development Review 17(3): 552-79. 
Mohamed, S.E and M.G. Sidiropoulos (2010), "Another look at the determinants of foreign direct investment in MENA countries: An empirical investigation," Journal of Economic Development 35(2): 75-95.

Neumayer, E. and L. Spess (2005), "Do bilateral investment treaties increase foreign direct investment to developing countries?" World Development 33(10): 1567-85.

Nonnenberg, M. and M. Mendonça (2005), "Determinantes do IDE em países em desenvolvimento," Estudos Economicos 35(2): 631-55.

Organisation for Economic Cooperation and Development (OECD) (2012), "Attracting knowledge-intensive FDI to Costa Rica: Challenges and policy options," Making Development Happen Series 1, OECD Development Centre.

Oneal, J. (1994), "The affinity of foreign investors for authoritarian regimes," Political Research Quarterly 47(3): 565-89.

Pastor, M. and E. Hilt (1993), "Private investment and democracy in Latin America," World Development 21(4): 489-507.

Porzecanski, R. and K. Gallagher (2007), "Economic reform and foreign direct investment in Latin America: A critical assessment," Progress in Development Studies 7(3): 217-33.

Ramirez, M. (2010), "Economic and institutional determinants of FDI flows to Latin America: A panel study," Trinity College Department of Economics Working Paper 10-03.

Root, F.R. and A.A. Ahmed (1978), "The influence of policy instruments on manufacturing direct foreign investment in developing countries," Journal of International Business Studies 9(2): 81-93.

Santana, J. and G. Vieira (2005), "Factores de atracção do IDE na América Latina: O papel da abertura económica," Revista da Fapese 2(1): 37-50.

Thorn. R. (1968), "Per capita income as a measure of economic development," Journal of Economics, 28(2): 206-16.

Transparency International (2012), "What is the corruption perceptions index (CPI)?" at http://cpi.transparency.org/cpi2012/in_detail/\#myAnchor1, accessed on December 18, 2012.

Treviño, J. and F. Mixon (2004), "Strategic factors affecting foreign direct investment decisions by multinational enterprises in Latin America," Journal of World Business 39(3): 233-43.

Tuman, J. and C. Emmert (1999), "Explaining Japanese foreign direct investment in Latin America, 1979-1992," Social Science Quarterly 80(3): 539-55.

United Nations Conference on Trade and Development (UNCTAD) (2010), World investment report 2010: Investing in a low-carbon economy. Geneva: United Nations.

UNCTAD (2012), World investment report 2012: Towards a new generation of investment policies. Geneva: United Nations.

UNCTAD (2013a). Investment country profiles: Chile. Geneva: United Nations.

UNCTAD (2013b). Investment country profiles: Mexico. Geneva: United Nations. 
Vijayakumar, N., P. Sridharan, and K.C.S. Rao (2010), "Determinants of FDI in BRICS countries: A panel analysis," International Journal of Business Science and Applied Management 5(3): 1-13.

Yang, J.Y.Y., N. Groenewold, and M. Tcha (2000), "The determinants of foreign direct investment in Australia," The Economic Record 76(232): 45-54.

$\mathrm{Yu}, \mathrm{T}$. and M. Zhang (2007), "Multivariate analysis of foreign direct investment in China," Journal of Applied Business Research 23(2): 21-9. 


\section{APPENDIX}

Figure A1.Cluster analysis dendrogram (2005): Furthest neighbor method

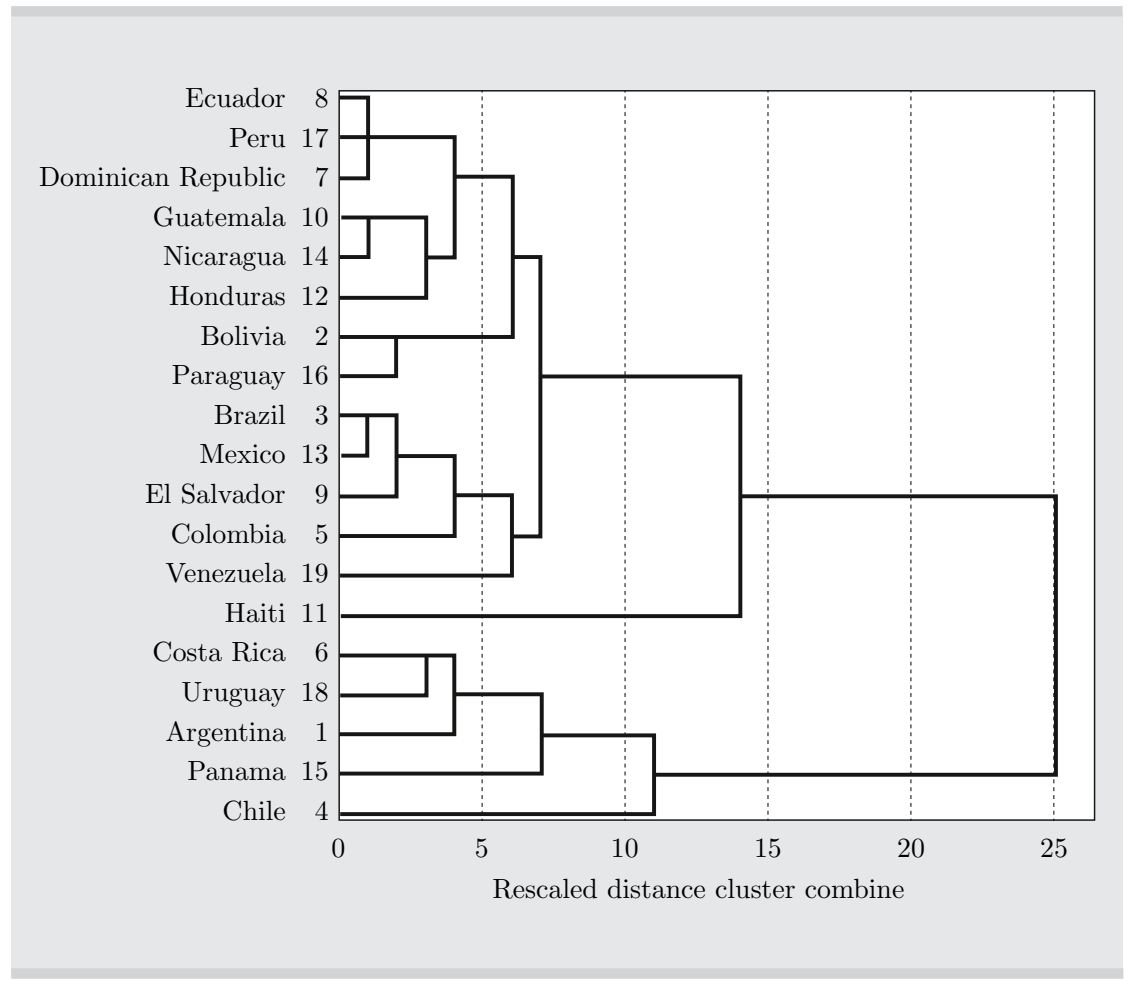

Source: Authors' calculations, using SPSS. 


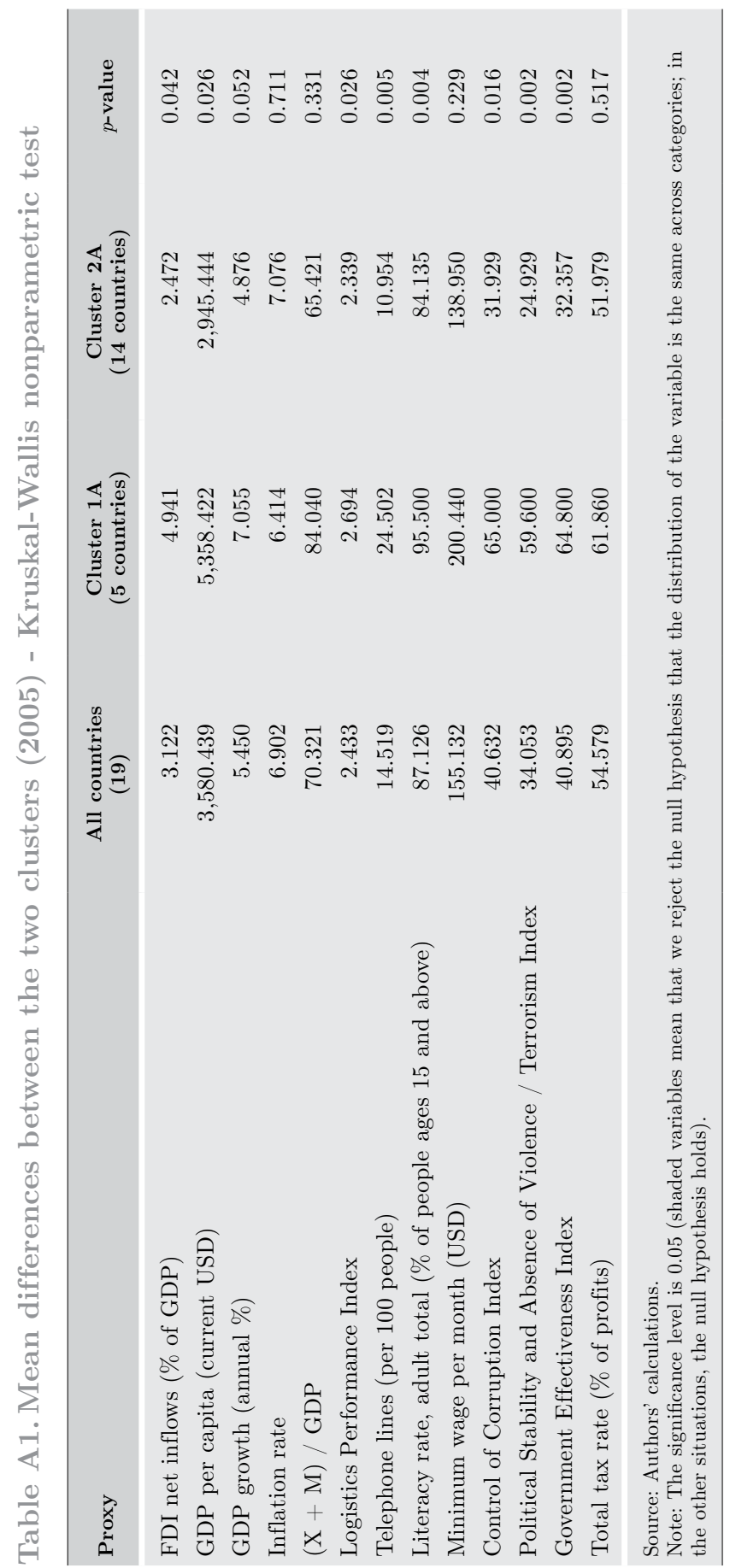

